\title{
Development Of Precission Farming Hydropoonic Model Based On Internet Of Things Using Arduino
}

\author{
Budi Tjahjono ${ }^{1}$, Kundang Karsono ${ }^{2 *}$, Lista Meria ${ }^{2}$ \\ 1,2,3 Computer Science Faculty, Universitas Esa Unggul \\ Jakarta, Indonesia. \\ *Corresponding Author: \\ Email: kundang.karsono@esaunggul.ac..id
}

\begin{abstract}
.
Agricultural land in urban areas was needed for community food security. Narrow agricultural land posed obstacles in the implementation of urban agriculture. Hydroponi is a solution for agricultureal development on narrow land. Precesion farming was needed to maintain plant growth. Hydroponic system required regulation of air and water temperature, humidity, water level, $p H$, water nutrient. This study used SDLC methodology. The result of this research is an automatic hydroponic implementation that can monitor and control an Internet of Things based hydroponic system using Arduino.
\end{abstract}

Keywords: Precission, farming, IoT, hydroponic, arduino

\section{INTRODUCTION}

Hydroponics is a planting system without soil. Hidroponics is one solution to plant cultivation without depending on soil and weather[1]. The advantage of hydroponic cultivation compared to conventional cultivation is that growth can be controlled. Among them are nutrients, water $\mathrm{pH}$, water temperature etc. The possibility of getting sick can also be minimized because of using a greenhouse. The harvest can also be done continuously without being influenced by the weather and season[2]. Hydroponics can be done on a narrow area [3].

Affective and efficient because it has to do monitoring every day so it must use energy, time of course work costs for monitoring and controlling plants[4]. Yields can alsdo be poor because they do not understand the available soil content. Precision farming is required in order to obtain good and quality harvests [5]. Therefore, this study will discuss the implementation of the Internet of Things (IoT) for monitoring and controlling hydroponic plants-6]. Because there are still many farmer working on their agricultural land conventionally, this research will build an automatic hydroponic control system using sensors for air temperature, water temperature, humidity, nutrient levels in water and monitoring is done in real time based on the Internet of Things (IoT) using Arduino 


\section{METHODS}

\section{Precission Farming}

\section{Arduino}

Arduino is an open source physical platform. Arduino is not only a tool for development, but Arduino is a combination of hardware and sophisticated programming language and Integraded Development Environment (IDE)[7][8]. IDE is software for writing programs, compiling binary code and uploading it to a memory controller. Arduino has developed into a platform for developing and creating solutions to various problems. One of the advantages of Arduino is that it is open source so it is permissible and legal for anyone to use it. Arduino is an open source physical platform. Arduino is not only a tool for development, but Arduino is a combination of hardware and sophisticated.

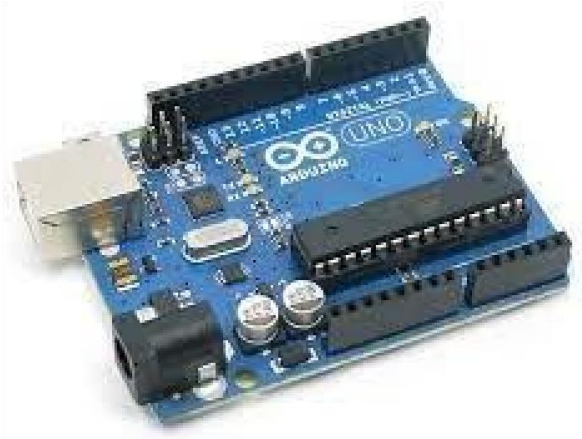

Fig 1. ArduinoUno

\section{Temperature Sensor}

The temperature sensor used is the DS18B20. This sensor is an electronic component that capture changes in environmental temperature. After that, the temperature is converted into an electric quantity. This sensor is capable of reading temperature with an accuracy of 9 to 12 bits with a temperature range between $-55^{\circ} \mathrm{C}$ to $125^{\circ} \mathrm{C}$. With accuracy $\left(0.5^{\circ} \mathrm{C}\right)$. For water temperature in hydroponics the optimal range is between $12{ }^{\circ} \mathrm{C}$ to $28^{\circ} \mathrm{C}$ while the air temperature is between $26^{\circ} \mathrm{C}$ to $31^{\circ} \mathrm{C}[8]$.

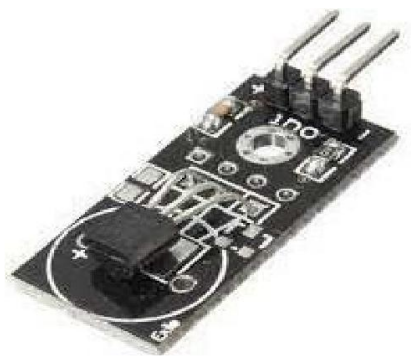

Fig 2. Temperature Sensor 


\section{Humidity Sensor}

In this study, the humidity sensor used is BME280, which is a sensor that functions to measure temperature, barometric pressure using the interface. The optimum air humidity in hydroponic plant is $70 \% \mathrm{RH}$ or with a range between $67 \%$ RH to $73 \%$ RH (Relative Humidity)[9]..

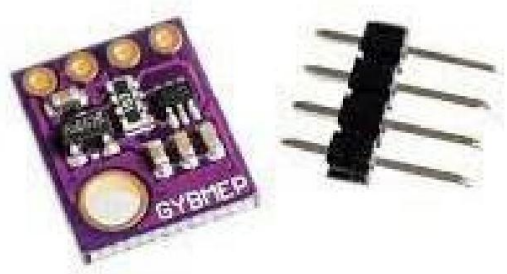

Fig 3. Humidity Sensor

\section{Ultrasonic Proximity Sensor}

Research using ultrasonic sensor type HC-SR04 is a sensor that works at 40KHz. HC-SR04 is an ultrasonic sensor that measures between the barrier and the sensor. The sensor is used to detect the water level in hydroponic plant tubs in a deep water culture system with an optimal height setting of $18 \mathrm{~cm}$ from the base [10].

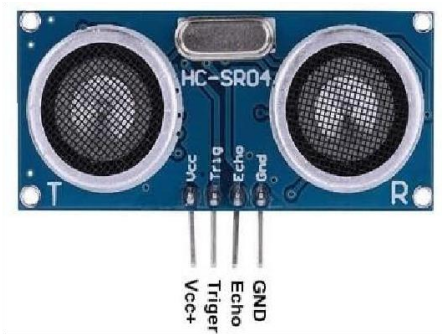

Fig 4. Ultrasonic Sensor

\section{pH Sensor}

$\mathrm{pH}$ is a measure that indicates the degree of acidity or alkalinity of a solution, $\mathrm{pH}$ is measured in the range from 0 to 14 . The ideal hydroponic water $\mathrm{pH}$ has an optimum $\mathrm{pH}$ of 6.0 or have a range between 5.5-6.5[11][12[

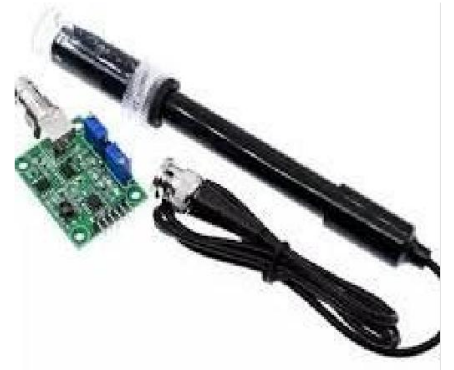

Fig 5. pH Sensor 


\section{Nutrition Sensor}

TDS (Total Dissolve Solid) or also known as PPM (Parts per Million) or the amount of solids contained in water. Every liquid contains dissolved particles even though they are not visible directly. Particles/solids can contain various metal content such as aluminium, copper, iron etc. Liuids alsdo contain non solid particles sch as microorganisms. Hydroponic has a TDS size of between $70 \%-80 \%$ of the water volume or less than 2599PPM [13].

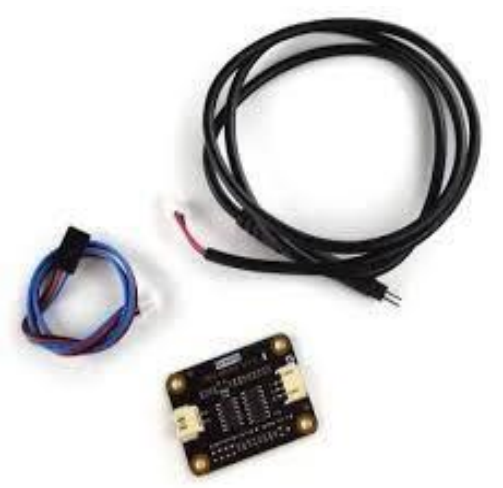

\section{Wi-Fi Sensor}

Fig 6. Nutrition Sensor

The wifi sensor used in this study is the ESP 8266 ESP-12F which is used as IoT (Internet of Things) which allows the microcontroller to access the WiFi network. This sensor uses UART by connecting its RX and TX pins. The VCC voltage given is $3.3 \mathrm{~V}$, not $5 \mathrm{~V}$.

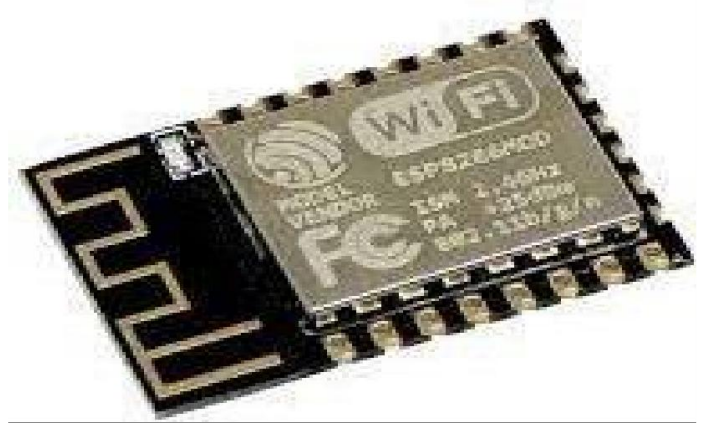

Fig. 7 Wi-Fi Sensor

\section{RTC DS3231 Module}

Real time Clock (RTC) module is a module that functions as a digital timer and adds a temperature measurement feature that is packaged in 1 module. The module is used to show the time to e displayed in the LCD layer. 


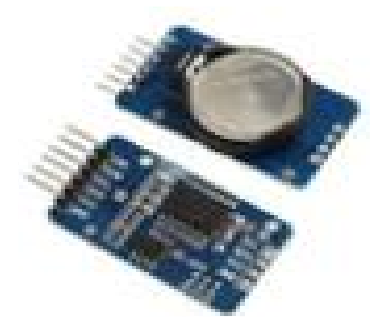

\section{LCD Display}

Fig 8. RTC DS3231 Module

LCD (Liquid Crystal Display) is an electronic component that funcgions to display data, both characters, letters and graphics. LCD is used when displaying measurement data display from sensors. The type of LCD used is the 2004 LCD with 4 lines $\times 20$ characters/line.

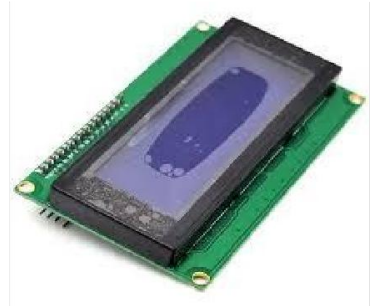

Fig 9. LCD Display

\section{Actuator}

The actuator is the output action of an Arduino process. The actuator will work when the output voltage is $5 \mathrm{~V}$ from the Arduino Uno microcontroller. The Arduino Uno output will turn on the relay to turn on the $220 \mathrm{~V}$ actuator. The actuators of each sensor can be described in the table below

Table 1. Actuator for Sensor

\begin{tabular}{|c|c|c|}
\hline No. & Sensor & Actuators \\
\hline 1. & Air Temperature & Fan \\
\hline 2. & $\begin{array}{c}\text { Water } \\
\text { Temperature }\end{array}$ & $\begin{array}{c}\text { Ventury } \\
\text { Pump }\end{array}$ \\
\hline 3. & Humidity & Exhaust Fan \\
\hline 4. & Nutrition (TDS) & $\begin{array}{c}\text { Solenoid } \\
\text { Valve }\end{array}$ \\
\hline 5. & $\mathrm{pH}$ & $\begin{array}{c}\text { Solenoid } \\
\text { Valve }\end{array}$ \\
\hline 6. & Ultrasonic & Water Pump \\
\hline
\end{tabular}




\section{ThingSpeak $^{\mathrm{TM}}$}

ThingSpeak is part of the Internet of Things application which is an open source application and API where users can collect, store, analyze the results of sensor and microcontroller data processing such as Arduino, Raspberry Pi and others. ThingSpeak uses http over the internet or uses a local area network. ThingSpeak is an application that collect data from nodes where it is possible to retrieve data through a software environment to analyze historical data. ThingSpeak can be accessed through the website http://thingspeak.com

\section{RESULT AND DISCUSSION System Planning}

In an augtomatic hydroponic system, it will be attached to a special place where the nutrients are sent directly to the hydroponic nutrient tank at a certain time. Arduino microcontroller will control all data and turn on the actuator automatically. To run this system, program modules are embedded in this system. Arduino microcontroller will process in real time to set and activate the actuator. The actuator will turn on automatically under certain conditions and provide action and stop until the conditions are met. To support the system, the ThingSpeak application is applied to smartphones and functions for monitoring hydroponic plants. The LCD layer is used to display sensor reading data. It will also show the system update time and date.The air and water temperature sensor (DS18B20) detects the temperature in ${ }^{\circ} \mathrm{C}$. Humidity sensor (BME280) detects air humidity using uits of \% RH (Relative Humidity). Sensor water level detects water level in hydroponic planting tanks using parameter in $\mathrm{cm}$. For height sensors using ultrasonic sensor (HC-SR04).

This sensor will adjust water level based on ultrasonic waves. Ultrasonic sensors will detect using the time of sending and receiving time in representing the distance between the sensor and the water. The TDS sensor measure the nutrient content in the solution in PPM units. The $\mathrm{pH}$ sensor does not have units, it has a value range from 1 to 14 . With a value of 7 is neutral $\mathrm{pH}$. $\mathrm{pH} 1-6$ is acidic $\mathrm{pH}$ and 8-14 is alkaline $\mathrm{pH}$. The picture below illustrates the design of an automatic system, namely the system begins with the work of a sensor connected to an electrode that will send data from the sensor to the Arduino microcontroller. The electrode output will be forwarded to the Arduino microcontroller. The microcontroller will capture the voltage and then process it. The result of the microcontroller process will be displayed on the LCD layer and sent via the WiFi sensor to the smartphone. Where the microcontroller will compare the previous values and make decisions based on data from the input sensor. Based on these data, the microcontroller will activate the actuator (on/off) according to predetermined conditions. 


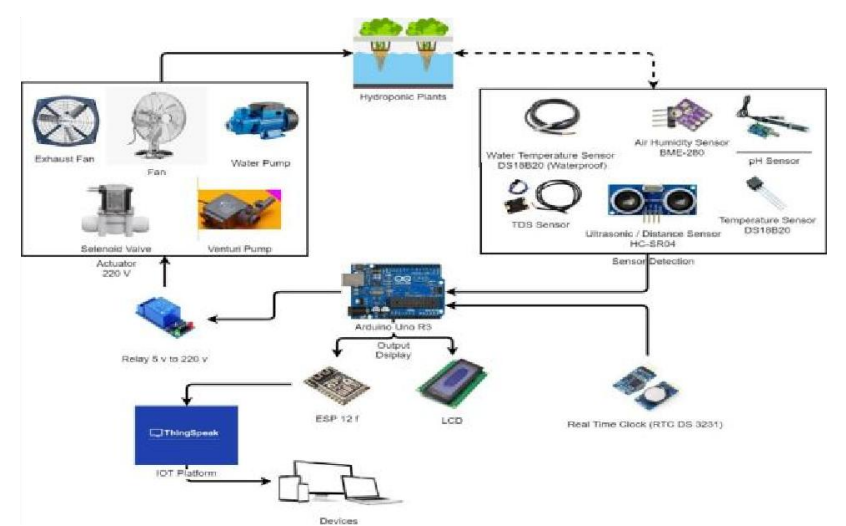

Fig 10. System Planning

System testing is the process of validating hardware and software systems in order to process conditions as expected. Tests are carried out after determinant the standard requirement that must be met by the system according to precision farming. Testing is done by comparing the performance of the system with actual conditions. Tests are carried out on input and output.The hardware will check the integrated components and modules whether they work according to the expected functions and standards. The next test is a test of sending data to a smartphone and sending it to ThingSpeak.

\section{Arduino Test}

Arduino testing is useful to determine the performance of the developed data delivery system. Testing data transmission using Arduino IDE Software, namely monitoring data using the Arduino IDE serial monitor feature. This test is caried out first bya programming the Arduino IDE using the Arduino C language. The next stage is compiling and uploading it on the Arduino microcontroller board

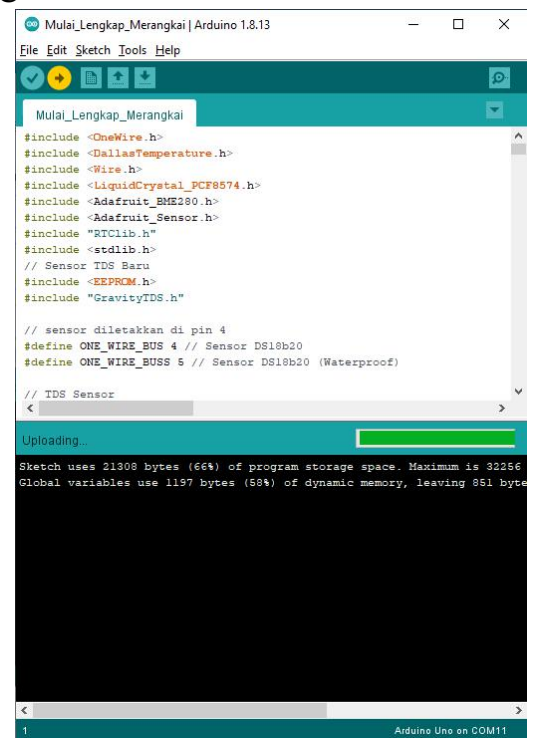

Fig 11. Arduino Test

http://ijstm.inarah.co.id 


\section{Sensor Test}

Table 2. Sensor Test Result

\begin{tabular}{|c|c|}
\hline Sensor & Result \\
\hline $\begin{array}{c}\text { Air temperature } \\
\text { (DS18B20) }\end{array}$ & Success \\
\hline $\begin{array}{c}\text { Suhu Air } \\
\text { (DS18B20) }\end{array}$ & Success \\
\hline Ultrasonik (HC-SR04) & Success \\
\hline TDS (Nutrtion) & Success \\
\hline pH(water) & Success \\
\hline $\begin{array}{c}\text { Humidity } \\
\text { (GY-BME 280) }\end{array}$ & Success \\
\hline ESP 8266 & Success \\
\hline
\end{tabular}

\section{ThingSpeak test.}

In the ThingSpeak test, the test results can be seen on the Thingspeak web. It can be seen that all the data on the sensors described have been successfully sent and declared successful as expected. Monitoring results on this system can be viewed https://hingspeak.com/channels/1303269 or can also be viewed on smartphones by downloading the Thingspeak application on the App Store or Play Store on channer 1303269. The result of the Thingscpeak test can be seen in the image below.

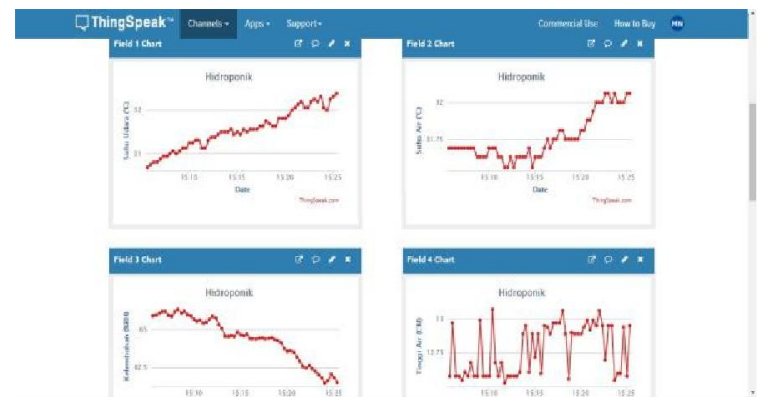

Fig 12. ThingSpeak Test

\section{System Test Result}

System testing can be seen in the table below:

Table 3. System Test

\begin{tabular}{|c|c|c|c|c|}
\hline No. & Tested Case & $\begin{array}{c}\text { Test } \\
\text { Scenario }\end{array}$ & $\begin{array}{l}\text { Expected } \\
\text { result }\end{array}$ & $\begin{array}{r}\text { Test } \\
\text { Result }\end{array}$ \\
\hline 1 & $\begin{array}{l}\text { Air Temp } \\
\text { (DS18B20) }\end{array}$ & $\begin{array}{l}\text { Measure Air } \\
\text { Temp }\end{array}$ & $\begin{array}{l}\text { Display data to } \\
\text { LCD }\end{array}$ & Success \\
\hline 2 & $\begin{array}{l}\text { Water temp } \\
(\mathrm{ds} 18 \mathrm{~b} 20)\end{array}$ & $\begin{array}{l}\text { Measure } \\
\text { water temp }\end{array}$ & $\begin{array}{l}\text { Display data to } \\
\text { LCD }\end{array}$ & Success \\
\hline 3 & $\begin{array}{l}\text { Ultrasonic(hc- } \\
\text { sr04) }\end{array}$ & $\begin{array}{l}\text { Measure } \\
\text { water level }\end{array}$ & $\begin{array}{l}\text { Display data to } \\
\text { LCD }\end{array}$ & Success \\
\hline
\end{tabular}




\begin{tabular}{|l|l|l|l|l|}
\hline $\mathbf{4}$ & $\begin{array}{l}\text { TDS } \\
\text { (Nutrition) }\end{array}$ & $\begin{array}{c}\text { Measure } \\
\text { water } \\
\text { nutrition }\end{array}$ & $\begin{array}{l}\text { Display data to } \\
\text { LCD }\end{array}$ & Success \\
\hline $\mathbf{5}$ & pH (Water) & $\begin{array}{c}\text { Measur water } \\
\text { pH }\end{array}$ & $\begin{array}{l}\text { Display data to } \\
\text { LCD }\end{array}$ & Success \\
\hline $\mathbf{6}$ & Humidity & $\begin{array}{c}\text { Measure } \\
\text { humidity }\end{array}$ & $\begin{array}{l}\text { Display data to } \\
\text { LCD }\end{array}$ & Success \\
\hline $\mathbf{7}$ & $\begin{array}{c}\text { Time Sensor } \\
\text { (RTC }\end{array}$ & $\begin{array}{c}\text { Display data } \\
\text { time }\end{array}$ & $\begin{array}{l}\text { Display data to } \\
\text { LCD }\end{array}$ & Success \\
\hline $\mathbf{8}$ & ESP231) 8266 & $\begin{array}{c}\text { Send sensor } \\
\text { data to web }\end{array}$ & $\begin{array}{l}\text { Pass sensor data } \\
\text { to Thingspeak }\end{array}$ & Success \\
\hline $\mathbf{9}$ & Relay & $\begin{array}{c}\text { Set the action } \\
\text { according to } \\
\text { the program }\end{array}$ & $\begin{array}{l}\text { It can adjust } \\
\text { actuator } \\
\text { according to the } \\
\text { programmed }\end{array}$ & Success \\
\hline $\mathbf{1 0}$ & LCD & $\begin{array}{c}\text { Display } \\
\text { sensor data }\end{array}$ & $\begin{array}{l}\text { Can display } \\
\text { sensor data } \\
\text { clearly }\end{array}$ & Success \\
\hline & ThingSpeak & $\begin{array}{c}\text { Display } \\
\text { sensor data } \\
\text { using web }\end{array}$ & $\begin{array}{l}\text { Can display } \\
\text { sensor data using } \\
\text { web }\end{array}$ & Success \\
\hline
\end{tabular}

\section{CONCLUSION}

The conclusion from the implementation of precision farming using the Arduino-based Internet of Things is as follows:

1. The tool can automate the hydroponic system according to precision farming standards and work well..

2. Monitoring and control of precision conditions can be carried out properly.

3. ThingSpeak works well and hydroponic greenhouse monitoring can be done anywhere using Internet of Things technology

\section{ACKNOWLEDGMENTS}

The authors are grateful to the Esa Unggul University for supporting this project and PuriPonic Greenhouse for the place of research place. We also thank to Nizirwan fo the invaluable advice and support.

\section{REFERENCES}

[1] P. Nutrisi and D. A. N. Waktu, "Air Untuk Pola Cocok Tanam Hidroponik BerbasisMikrokontroler Avr Atmega 8535 Air Untuk Pola Cocok Tanam Hidroponik BerbasisMikrokontroler Avr Atmega8535,” 2008.

[2] U. Nurhasan, A. Prasetyo, G. Lazuardi, E. Rohadi, and H. Pradibta, "Implementation 
IoT in System Monitoring Hydroponic Plant Water Circulation and Control," Int. J. Eng. Technol.,vol. 7, no. 4.44, p. 122, 2018, doi:10.14419/ijet.v7i4.44.26965.

[3] I. A. Rozaq and N. Y. DS, "Uji Karakterisasi Sensor Suhu DS18B20 Waterproof BerbasisArduino Uno Sebagai Salah Satu Parameter Kualitas Air," Pros. SNATIF, vol. 0, no. 0, pp. 303-309, 2017.

[4] R. Vidhya and K. Valarmathi, "Automatic Monitoring of Hydroponics System Using IoT,”Lect. Notes Data Eng. Commun. Technol., vol. 35, no. June, pp. 641-648, 2020, doi: 10.1007/978-3-030-32150-5_62.

[5] V. Palande, A. Zaheer, and K. George, "Fully Automated Hydroponic System for Indoor Plant Growth,” Procedia Comput. Sci., vol. 129, pp. 482-488, 2018, doi: 10.1016/j.procs.2018.03.028.

[6] A. U. Rahmania and H. G. Ariswati, "Perancangan pH MeterBerbasis Arduino Uno," Elektromedik, vol. 1, pp. 22-30, 2018.

[7] Y. Setiawan, H. Tanudjaja, and S. Octaviani, "Penggunaan Internet of Things (IoT) untuk Pemantauan dan Pengendalian Sistem Hidroponik," TESLA J. Tek. Elektro, vol. 20, no. 2, p. 175,2019, doi:

10.24912/tesla.v20i2.2994.

[8] S. J. Sokop, D. J. Mamahit, and S.Sompie, “Trainer Periferal Antarmuka Berbasis Mikrokontroler Arduino Uno,” J. Tek. Elektro dan Komput., vol. 5, no. 3, pp. 13-23, 2016.

[9] A. T. Aulia Nurbaiti Mansyur, Sugeng Triyono, "Pengaruh Naungan Terhadap Pertumbuhan Sawi (Brassica Juncea L.). Pada Sistem Hidroponik DFT (Deep Flow Technique)," Psychol. Appl. to Work An Introd. to Ind. Organ. Psychol. Tenth Ed. Paul, vol. 53, no. 9, pp. 1689-1699, 2014.

[10] M. Majid, J. N. Khan, Q. M. Ahmad Shah, K. Z. Masoodi, B. Afroza, and S. Parvaze, "Evaluation of hydroponicsystems for the cultivation ofLettuce (Lactuca sativa L., var. Longifolia) and comparison with protected soil-based cultivation," Agric. Water Manag., no. August, p. 106572, 2020, doi:10.1016/j.agwat.2020.106572.

[11] S. Djamhari, "Biokompos Cair Dan Pupuk Kimia Npk Sebagai Alternatif Nutrisi Pada Budidaya Tanaman Caisim Teknik Hidroponik," J. Sains dan Teknol. Indones., vol. 14, no. 3, pp. 234-238,2013, doi:10.29122/jsti.v14i3.932.

[12] Y. H. Putra, D. Triyanto, and Suhardi, "Sistem Pemantauan dan Pengendalian Nutrisi, Suhu, dan Tinggi Air Pada Pertanian Hidroponik," J. Coding, Sist. Komput. Untan, vol. 06, no. 03, pp.128-138, 2018.

[13] Wada, T. (2018). Theory and Technology to Control the Nutrient Solution of Hydroponics. In Plant Factory Using Artificial Light: Adapting to Environmental Disruption and Clues to Agricultural Innovation. Elsevier Inc. https://doi.org/10.1016/B978-0-12-813973-8.00001-4 